\title{
PELATIHAN MARKETING PUBLIC RELATIONS BAGI STAKEHOLDERS PARIWISATA DI OBJEK WISATA STONE GARDEN BANDUNG BARAT
}

\author{
Susie Perbawasari 1), Dian Wardiana Sjuchro'), Yanti Setianti ${ }^{3)}$, Aat Ruchiat \\ Nugraha $^{4}$, Ayu Indra Wardhani ${ }^{5}$ \\ ${ }^{1,3,4}$ Hubungan Masyarakat, Fakultas Ilmu Komunikasi \\ ${ }^{2}$ Jurnalistik, Fakultas Ilmu Komunikasi \\ ${ }^{5}$ Hubungan Masyarakat, Kemenko Maritim \\ email: susie.perbawasari@unpad.ac.id
}

\begin{abstract}
The trend of Muslim tourism continues to increase along with the awareness of Muslims to apply the Muslim lifestyle. The Muslim lifestyle affected the demands of halal tourism packages - one of the attractions that are trying to hold a halal tour package, namely Stone Garden. Several obstacles are found related to the realization of Stone Garden into halal tourist destinations, namely the limited human resources, infrastructure, facilities, and coaching patterns from the manager. To foster human resources in the activities of tourism services and tourism promotion needs to be improved through the implementation of Marketing Public Relations training for tourism destination managers in facing the challenges of the increasingly globalized tourism market. The training held at the Stone Garden Tourism Awareness Group secretariat with participants from tourism agents, tourist managers, and tour guides. The training methods used are discussion, lecture, and case simulation. The results of the training showed that the knowledge and communication skills of Marketing Public Relations communication among the actors, managers, and tour guides in the Stone Garden area experienced a considerable increase which was shown by participants understanding the importance of communication in communitybased tourism management.
\end{abstract}

Keywords: Marketing Public Relations, Training, Tourism, Stakeholders, Halal Tourism

\begin{abstract}
Abstrak
Trend wisata muslim terus meningkat seiring dengan adanya kesadaran umat muslim untuk menerapkan gaya hidup muslim. Gaya hidup muslim tersebut berimbas pada tuntutan paket pariwisata halal. salah satu objek wisata yang sedang mencoba untuk menyelenggarakan paket wisata halal yaitu Stone Garden. Ada beberapa kendala yang ditemukan berkaitan dengan perwujudan Stone Garden menjadi destinasi wisata halal yaitu terbatasnya sumber daya manusia, infrastruktur, fasilitas, dan pola pembinaan dari pihak pengelola. Untuk pembinaan sumber daya manusia dalam aktifitas pelayanan jasa wisata dan promosi wisata perlu ditingkatkan melalui penyelenggaraan pelatihan Marketing Public Relations bagi pengelola destinasi wisata dalam menghadapi tantangan pasar pariwisata yang semakin mengglobal. Pelatihan ini diselenggarakan di sekretariat Kelompok Sadar Wisata Stone Garden dengan peserta berasal dari pelaku wisata, pengelola wisata, dan pemandu wisata. Adapun metode pelatihan yang digunakan adalah diskusi, ceramah, dan simulasi kasus. Hasil pelatihan menunjukkan bahwa pengetahuan dan kemampuan praktek komunikasi Marketing Public Relations di kalangan para pelaku, pengelola, dan pemandu wisata di kawasan Stone Garden mengalami peningkatan secara baik yang ditunjukkan dengan peserta memahami pentingnya komunikasi dalam pengelolaan pariwisata yang berbasiskan masyarakat.
\end{abstract}

Kata Kunci: Marketing Public Relations, Pariwisata Berbasis Masyarakat, Pelatihan, Stakeholders, Wisata Hala. 


\section{PENDAHULUAN}

Pariwisata telah ditetapkan sebagai leading sector oleh Presiden Republik Indonesia Joko Widodo dalam sebuah rapat terbatas dan pernyataan itu sesuai dengan salah satu program Nawacita pemerintahan Republik Indonesia tahun 2014 - 2019. Di mana pertumbuhan sektor pariwisata pada tahun 2017 naik sebesar 22 persen secara global dan menjadi negara dengan pertumbuhan kedua terbesar di kawasan ASEAN. Selain pertumbuhan pariwisata secara umum, kenaikan juga terdapat pada kunjungan wisatawan Muslim ke Indonesia. Tercatat Indonesia meraih posisi kedua berdasarkan Indonesia Ranks At The Global Muslim Travel Index (GMTI) pada tahun 2018. Terkait dengan proyeksi kunjungan wisatawan muslim, Indonesia memiliki potensi yang sangat luar biasa baik dalam aspek sumber daya alam maupun sumber daya manusia. Sebagaimana hal ini didukung oleh pernyataan dari hasil penelitian (Ade Ela Pratiwi, 2016) yang menunjukkan bahwa Indonesia dengan berpenduduk mayoritas muslim sebanyak $87,18 \%$ akan menjadi modal dasar sosial untuk menjadi tuan rumah pariwisata halal yang baik dengan jumlah umat muslim Indonesia merupakan yang tertinggi dari negaranegara di dunia yang mencapai 207 juta orang. Selain sebagai negara Muslim terbesar di dunia, Indonesia juga menjadi destinasi pilihan para wisatawan Muslim dari negara - negara Muslim lain di Asia dan Timur Tengah seperti Uni Emirat Arab. Trend ini terus meningkat seiring dengan kesadaran umat Muslim untuk menerapkan gaya hidup Muslim yang disebut juga dengan Halal Lifestyle. Umat Muslim yang berasal dari kelas menengah dan kelas atas tidak berkeberatan untuk mengeluarkan biaya lebih besar untuk mendapatkan kenyamanan berwisata namun tetap dapat menjalankan kewajibannya sebagai umat Islam. Indonesia sebagai negara Muslim dianggap sebagai salah satu destinasi wisata yang cocok dan dapat memenuhi harapan wisatawan Muslim saat berlibur.

Menurut (Adinugraha, Sartika, \& Kadarningsih, 2018) wisata halal merupakan implementasi perwujudan dari nuansa religiusitas yang tercakup di dalam aspek mu'amalah sebagai pengejawantahan aspek kehidupan sosial budaya dan sosial ekonomi yang berlandaskan prinsip-prinsip syariah. Wisata halal (halal tourism) sendiri didefinisikan sebagai aktivitas berwisata yang dilakukan dalam keadaan dan didukung oleh destinasi serta fasilitas yang memenuhi unsur syariat Islam. Destinasi dan penunjang aktivitas halal tourism yang memenuhi syariat Islam, seperti: 1) makanan dan minuman halal, 2) tempat dan sarana beribadah, 3) ketersediaan ruang privasi antara lakilaki dan perempuan. Kebutuhan untuk menyediakan layanan wisata halal kemudian menjadi urgensi bagi beberapa daerah kota dan kabupaten agar menjadi menarik dan nyaman bagi pengunjung muslim. Salah satunya adalah kota Bandung yang memiliki banyak peluang untuk dapat dimanfaatkan sebagai percontohan pengembangan wisata halal, dikarenakan rerata masyarakatnya penduduk muslim, kemampuan akses ke berbagai destinasi pariwisata yang semakin berkembang, dan adanya daya tarik wisata yang meningkat dari sisi pelayanan wisata. Dengan adanya kondisi wisata halal yang semakin terbuka maka mampu berperan dalam mendorong pertumbuhan ekonomi di Kota Bandung (Pratiwi, Dida, \& Sjafirah, 2018).

halal $\begin{gathered}\text { Adanya peluang konsep wisata } \\ \text { dalam }\end{gathered}$ perekonomian, kabupaten Bandung Barat yang terdorong untuk mewujudkan beberapa kawasan wisata halal dengan kekhasan masing-masing dari potensi 
wisata tersebut. Adapun keberadaan destinasi wisata populer di wilayah Kabupaten Bandung Barat diantaranya Lembang, Tangkuban Perahu, Taman Bunga Anggrek, dan Stone Garden. Area wisata Stone Garden berada di atas Gunung Pawon, kampung Girimulya desa Gunung Masigit kecamatan Cipatat kabupaten Bandung Barat, Jawa Barat. Objek pariwisata Stone Garden merupakan kawasan hamparan luas dengan batu karst yang tersusun indah secara alami yang merupakan peninggalan zaman purbakala. Hal ini diperkuat oleh pernyataan Ketua Kelompok Sadar Wisata (Pokdarwis) Pasir Pawon dan Stone Garden, Sukmayadi Suwerna, yang menyebutkan bahwa Stone Garden merupakan situs laut purbakala yang terbentuk hasil dari letusan gunung berapi dan gesekan lempeng bumi sekitar 30 juta tahun lalu. Pada akhirnya, selama proses pembentukan berjuta-juta tahun mengangkat permukaan Stone Garden ke daratan hingga 900 meter di atas permukaan laut (mdpl).

Keberadaan wilayah destinasi wisata Stone Garden tersebut dikelola oleh masyarakat secara mandiri dan bergotong royong dengan swakelola secara bergantian diantara pengurus pemerintahan desa dan pemilik lahan. Dengan melihat potensi wisata di Stone Garden tersebut dapat dikatakan cukup maju, sehingga para pengelola berkeinginan untuk dapat lebih meningkatkan pengelolaan kawasan wisata Stone Garden menjadi lebih bermartabat dan "Islami". Usulan konsep ini dilatarbelakangi dengan semakin "sumpek" nya destinasi di kota Bandung yang akan menjadi peluang menarik bagi para wisatawan muslim untuk berkunjung ke Stone Garden yang memiliki ciri khas sebagai destinasi wisata unggulan di Kabupaten Bandung Barat yang bermaterialkan nuansa kepurbakalaan dan berbasis budaya. Di sisi lain, untuk memenuhi kebutuhan wisatawan muslim yang jumlahnya semakin bertambah dari tahun ke tahun dan yang dapat memberikan branding khusus pada Stone Garden sebagai salah satu objek wisata halal di Kabupaten Bandung Barat ke depannya. Hal ini sebagaimana yang diutarakan dari hasil kajian bahwa keunikan suatu daerah dapat menjadi potensi daya tarik wisata bagi suatu daerah (Anugrah, Mokodongan, \& Pulumodoyo, 2017).

Jika merujuk pada syarat penunjang sebuah destinasi wisata menjadi wisata halal antara lain harus memennuhi standar mengenai ketersediaan makanan dan minuman halal, tempat dan sarana beribadah muslim dan ruang privasi antara laki-laki dan perempuan. Sedangkan objek wisata Stone Garden belum memiliki ketiganya, seperti makanan dan minuman yang dijual masih bersifat tradisional, tempat sarana ibadah (masjid/mushola) yang sangat minim karena keberadaan air untuk bersuci yang tidak tersedia dalam jumlah yang cukup, dan tidak tersedianya ruang privasi antara lakilaki dan perempuan bagi pengunjung. Keadaan ini menjadi kendala utama untuk mewujudkan keinginan menjadikan Stone Garden sebagai objek wisata halal yang layak. Hambatan ini disebabkan dalam proses pengelolaannya masih sangat terbatas baik dari segi sumber daya manusia, infrastruktur, fasilitas, dan pembiayaan yang masih mengandalkan dari retribusi wisata. Selain itu, fakta di lapangan menunjukkan bahwa sumber daya manusia yang ada di wilayah Stone Garden masih memerlukan pembinaan khusus dalam melakukan pelayanan jasa wisata, komunikasi, dan aktivitas promosi.

Hal utama dalam mewujudkan Stone Garden menuju wisata halal adalah dari sisi pengkomunikasian ke publik. Untuk kegiatan komunikasi, 
khususnya mengenai Marketing Public Relations menjadi sangat penting dalam menghadapi tantangan promosi dan jasa pariwisata bagi wisatawan yang berkunjung ke Stone Garden. Melalui pelatihan Marketing Public Relations diharapkan dapat digunakan dalam menunjang mempromosikan Stone Garden melalui pendekatan dan metode komunikasi tradisional maupun yang diintegrasikan dengan perkembangan teknologi informasi tanpa memerlukan biaya yang besar. Namun, faktanya di lapangan, kemampuan keterampilan komunikasi para pengelola, pemandu, dan pelaku usaha masih dinilai kurang terutama dalam penggunaan teknologi komunikasi dan kemampunan berbahasa asing. Kedua hal ini sangat penting untuk mempromosikan Stone Garden sebagai objek wisata halal kepada wisatawan domestik maupun internasional sebagai bagian dari pelaksanaan marketing public relations.

Berdasarkan permasalahan yang dihadapi oleh pengelola, pemandu, pelaku usaha di objek wisata Stone Garden Kabupaten Bandung Barat yang telah dipaparkan sebelumnya, maka dapat dirumuskan masalah yang menjadi urgensi kegiatan pengabdian ini, yaitu "Bagaimana penerapan pelatihan Marketing Public Relations pada pengelola, pemandu dan pelaku usaha dalam upaya menjadikan Stone Garden sebagai Destinasi Wisata Halal?"

\section{HASIL DAN PEMBAHASAN}

Adanya pengembangan sektor pariwisata diharapkan dapat mendorong terjadinya peningkatan kesejahteraan masyarakat lokal melalui penyediaan lapangan kerja yang didukung oleh berbagai pihak. Kegiatan pembangunan kepariwisataan, pada hakikatnya melibatkan peran dari tiga pemangku kepentingan yaitu pemerintah, swasta, dan masyarakat. Di mana keberadaan masyarakat di kawasan wisata Stone
Garden berperan sebagai pelaku wisata dengan manajemen pariwisata yang sederhana. Maka dari itu, sesungguhnya masyarakat menjadi salah satu unsur penting untuk bersama-sama dengan pemerintah dan swasta melaksanakan dan mendukung pembangunan kepariwisataan secara profesional (Safira, Perbawasari, \& Sani, 2018).

Dalam rangka mewujudkan kepariwisataan yang terkelola dengan baik, perlu dilakukan suatu pelatihan yang dapat meningkatkan kapasitas keterampilan bagi pengelola pariwisata di Stone Garden yang dikemas dalam bentuk program pengabdian kepada masyarakat dari Universitas Padjadjaran. Pelaksanaan kegiatan PKM dilakukan pada hari Rabu, 29 Agustus 2018 pada pukul 09.00 - $13.00 \mathrm{WIB}$, bertempat di ruang Gazebo Stone Garden Padalarang Kabupaten Bandung yang dihadairi oleh 30 orang peserta yang berasal dari pengelola, pemandu wisata, dan pelaku usaha di objek wisata Stone Garden yang melibatkan unsur tim dosen program studi Hubungan Masyarakat Fikom Unpad dan mahasiswa dalam bentuk pelatihan komunikasi pariwisata.

Adapun rangkaian kegiatan

PKM diawali dengan penyampaian materi mengenai pemetaan potensi, masalah dan solusi objek wisata Stone Garden dalam memenuhi kriteria sebagai objek wisata halal yang disampaikan oleh Dr. Dian Wardiana Sjuchro, M.Si. Narasumber melakukan simulasi dengan pendekatan design thinking untuk memetakan masalah dari peserta dan menawarakan solusi yang berdasarkan hasil pemikiran dari para peserta. Pada sesi ini didapatkan berbagai permasalahan utama yang dihadapi dalam mewujudkan Stone Garden sebagai wisata halal antara lain: masalah fasilitas, pungutan/retribusi, akses, keterampilan pemandu, dan ketersediaan informasi objek wisata. Selanjutnya, untuk materi teknik 
Marketing Public Relations disampaikan oleh Dr. Susie Perbawasari, M.Si, yang dimana serangkap sebagai ketua tim PKM dosen Prodi Humas Fikom Unpad.

Setelah materi disampaikan kemudian dilakukan proses tanya jawab dan simulasi yang dipimpin oleh Dr. Dian Wardiana Suhro, M,Si sebagai simulator dengan mestimulasi peserta untuk aktif memberikan solusi pada permasalahan yang dihadapi dalam pengelolaan, pengembangan dan aktvitas promosi objek wisata Stone Graden yang menggunakan kertas post it dan ditempelkan pada pohon masalah dan pohon solusi.

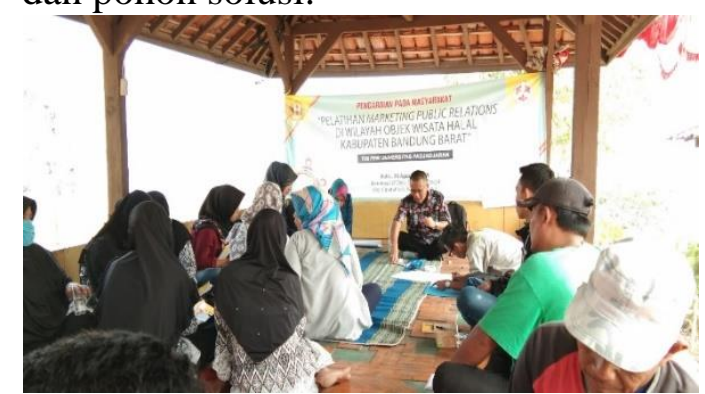

Gambar 1. Penyampaian Materi oleh Dr. Dian Wardiana Sjuchro

Dari hasil simulasi terkait dengan pemetaan mengenai kelayakan kondisi Stone Garden yang dicita-citakan oleh pengelola untuk dapat menjadi kawasan wisata halal, ternyata menunjukkan

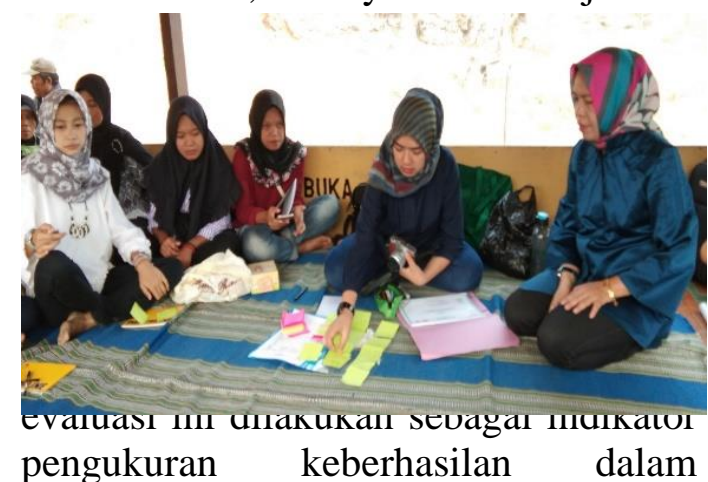

pelaksanaan kegiatan pengabdian pada masyarakat dari sisi perubahan kognitif yang dimiliki masyarakat mengenai materi kepariwisataan. Sedangkan untuk mengetahui keterampilan komunikasi dalam hal aktivitas Marketing Public Relations dari pengelola, pemandu wisata, dan pelaku usaha di objek wisata
Stone Garden, maka tim PKM melakukan kegiatan monitoring dan evaluasi secara berkala dan berkesinambungan yang bekerjasama dengan pihak pimpinan kelompok masyarakat yang ada di objek wisata Stone Garden yaitu Bapak Sukmayadi Suwerna selaku pimpinan kelompok sadar wisata untuk mendapatkan informasi mengenai perkembangan perubahan perilaku masyarakat dalam usaha mempromosikan potensi wisata setempat pasca pelatihan diberikan.

Keberadaan konsep pariwisata halal yang ingin dikembangkan di Stone Garden, diadopsi dari proyeksi wisata halal kota Bandung yang dikembangkan melalui dukungan dari berbagai lintas lembaga, yang disebut strategi penta helix. Strategi tersebut merupakan strategi komunikasi yang dilakukan oleh Dinas Pariwisata dan Kebudayaan provinsi Jawa Barat dalam mempersiapkan Kota Bandung sebagai destinasi wisata halal dengan melakukan sosialisasi untuk menumbuhkan kesadaran (awareness) kepada Satuan Kerja Perangkat Dinas (SKPD) terkait (Pratiwi et al., 2018).

Guna melengkapi proses penyampaian materi maka dilakukan beberapa metode sebelumnya berupa simulasi. Simulasi merupakan metode pelatihan yang memperagakan sesuatu dalam bentuk tiruan yang mirip dengan keadaan yang sesungguhnya. Simulasi yang dilakukan dalam pelatihan Marketing Public Relations ini adalah menuliskan berbagai tantangan dalam mewujudkan wisata halal yang dituangkan dalam bentuk pohon masalah beserta solusinya 


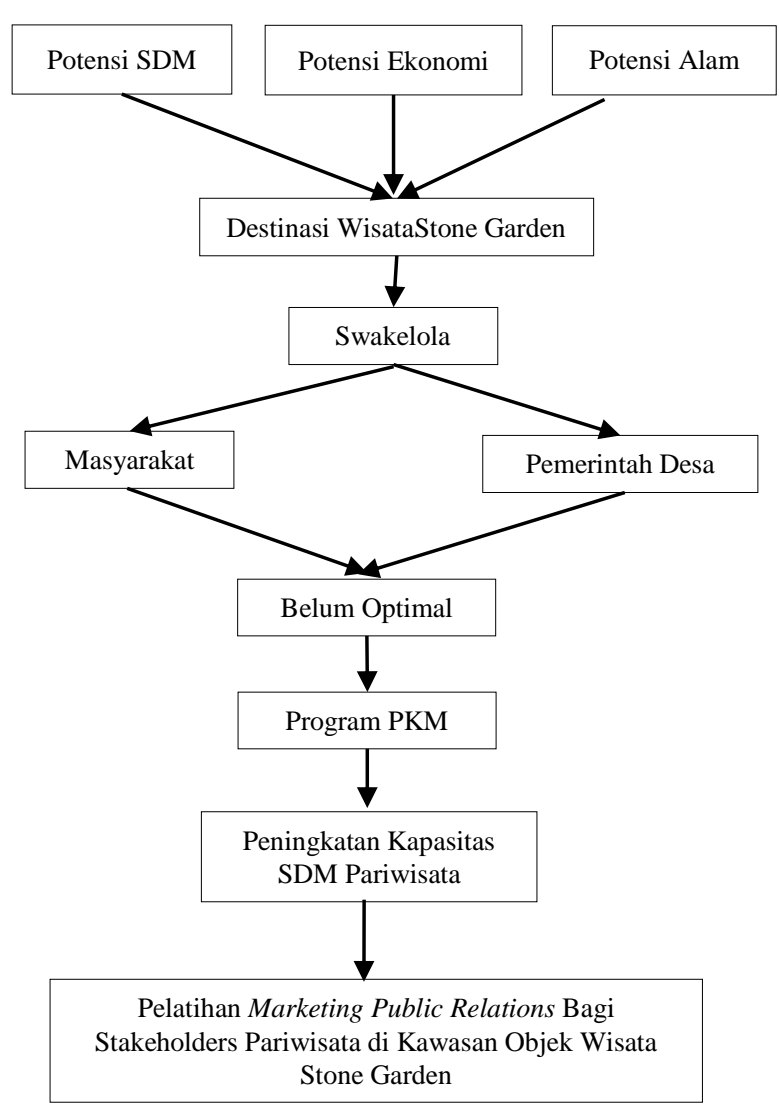

Bagan 1. Pola Pelaksanaan PKM Pelatihan Marketing Public Relations

Gambar 2. Proses Pelatihan Mapping Permasalahan Wisata Halal di Kawasan Wisata Stone Garden

Metode simulasi ini dilakukan dengan tujuan agar peserta dapat terlatih melakukan penyelesaian berbagai masalah yang akan timbul di kemudian hari terkait perwujudan wisata halal Stone Garden. Materi selanjutnya yang disampaikan dengan mengunakan metode ceramah tentang pengemasan informasi terkait objek wisata Stone Garden yang dapat dijadikan sebagai bahan promosi melalui komunikasi tatap muka maupun komunikasi bermedia misalnya media sosial. Promosi di media sosial sekarang ini sudah menjadi kewajiban bagi pengelola objek wisata agar dapat terus dikenal oleh masyarakat dengan memanfaatkan potensi narasi dan gambar (foto/video) yang dilakukan oleh pengelola maupun pengunjung.
Menurut Sagala (dalam Hardini \& Puspitasari, 2012) metode ceramah adalah sebuah bentuk interaksi melalui penerangan dan penuturan lisan dari pemateri kepada peserta. Metode ceramah merupakan cara belajar yang menekankan pada pemberitahuan informasi yang bersifat satu arah dari pemateri kepada peserta yang aktif maupun pasif.

Untuk metode diskusi dalam PKM ini, pemateri dengan peserta berbincang mengenai masalah dan solusi menghadapi tantangan pemenuhan kriteria wisata halal. Diskusi merupakan bentuk kegiatan tukar pikiran antara dua orang atau lebih tentang suatu masalah untuk mencapai tujuan melalui analisis, memecahkan masalah, menggali atau memperdebatkan suatu topik atau permasalahan tertentu. Sedangkan untuk metode tanya jawab yang dalam kegiatan pengabdian ini yaitu peserta menyampaikan beberapa pertanyaan secara tertulis maupun lisan yang lebih bersifat formal dengan dijawab berdasarkan sumber rujukan yang terpercaya (Hardini \& Puspitasari, 2012). Selain itu, dilakukan juga metode problem solving sebagai gabungan beberapa metode yang dirasa cukup penting dalam menyampaikan materi tentang teknik pengelolaan informasi ini. Problem solving adalah pola pembelajaran yang bersifat memecahkan masalah. Pada tingkat ini, peserta merumuskan masalah, memberikan tanggapan terhadap rangsangan yang menggambarkan atau membangkitkan situasi problematik yang menggunakan berbagai kaidah yang telah dikuasainya, khususnya terkait dengan permasalahan pembentukan modal sosial pariwisata halal di area Stone Garden.

Dalam mempermudah proses dasar pemikiran dari PKM di Stone Garden adalah berdasarkan hasil observasi awal tim PKM Universitas Padjadjaran yang menilai bahwa kawasan karst terutama 
Stone Garden memiliki potensi untuk dikembangkan menjadi objek wisata unggulan. Keunggulan nya tersebut berupa potensi sumber daya alam, potensi budaya, dan potensi ekonomi. Dengan ketiga potensi tersebut sesungguhnya dapat dikembangkan menjadi lebih profesional dalam mengelola suatu destinasi wisata. Namun, untuk sisi sumber daya manusia, keberadaannya masih sangat menyedihkan dikarenakan para pengelola wisata belajar secara otodidak dengan melibatkan berbagai unsur masyarakat untuk terlibat melestarikan lingkungan sekitar objek wisata

Untuk tingkat kesiapan Stone Garden menjadi objek wisata halal di kabupaten Bandung Barat masih begitu jauh. Namun, usaha dan upaya mewujudkan Stone Garden menjadi wisata halal terus dirintis oleh pengelola dengan berbagai cara mulai dari mengikuti kegiatan pelatihan, bimbingan teknis, bahkan sampai pada menerima bantuan pendanaan dari suatu perusahaan (CSR). Hal lainnya yang menjadi hambatan adalah kesadaran masyarakat mengenai potensi wisata halal yang masih berbeda-beda. Sehingga makna wisata halal ada yang mengartikan sebagai paket wisata yang menyajikan makanan dari bahan-bahan yang halal atau aturan perwisataan yang mengikuti tata cara dalam syari'at Islam (Salehudin dan Lutfi dalam Awalia, 2017).

Dalam hal pelaksanaan PKM, tim dosen Prodi Humas menyampaikan inti sambutannya bahwa kegiatan PKM ini merupakan bagian dari kegiatan Tri Dharma Perguruan Tinggi yang harus dilakukan oleh setiap dosen sebagai bentuk kewajiban terhadap negara. Kemudian sambutan disampaikan oleh Ketua Pokdarwis Pasir Pawon dan Stone Garden, Sukmayadi Suwerna yang menyatakan bahwa objek wisata Stone Garden berkeinginan untuk menjadi salah satu destinasi wisata halal namun sampai saat ini masih mengalami beberapa kendala termasuk salah satunya dalam bidang promosi.

Secara umum kegiatan PKM ini dinilai cukup berhasil dari segi perencanaan, pelaksanaan maupun hasil kegiatan pelatihan secara umum. Hal ini tergambar dari komentar, tanggapan, maupun permintaan peserta yang menginginkan kegiatan serupa baik dengan materi yang sama maupun yang berbeda. Ditinjau dari antusiasme para peserta diperoleh gambaran bahwa materi yang disampaikan oleh pemateri sesuai dengan kebutuhan para peserta yaitu menginginkan pengetahuan secara kognitif, afektif, dan konatif mengenai pengemasan informasi yang dapat dijadikan modal pelaksanaan promosi objek wisata Stone Garden sebagai destinasi wisata halal.

Dari sisi keberlanjutan program kegiatan PKM ini, untuk dapat menguasai kemampuan dalam aktivitas marketing public relations yang baik bukanlah mudah yang dapat dikuasai hanya dalam sekali kegiatan, perlu upaya berkelanjutan dan berkesinambungan agar kemampuan teknis para peserta dapat terkomunikasikan dengan baik melalui berbagai teknik-teknik praktis marketing public relations, seperti dalam bentuk pengemasan informasi dan dokumentasi kegiatan serta pemandangan alam Stone Garden menjadi lebih baik. Keberlanjutan dapat dilakukan terutama oleh pihak internal, dalam artian secara personal para peserta dapat mengasah terus kemampuan konatif berdasarkan pengetahuan yang sudah didapat. Adapun secara eksternal yaitu pihak-pihak di luar pengelola, pemandu wisata dan pelaku usaha yang terus memberikan kesempatan untuk meningkatkan keterampilan berkomunikasinya sebagai bagian kemampuan di bidang softskill, salah satunya melalui pemberian pelatihan 
yang lebih profesional dan berkelanjutan.

Setelah kegiatan ini dilaksanakan maka rencana keberlanjutan dari program ini ialah memberikan pendampingan yang menunjang peningkatan keahlian dan keterampilan marketing public relations bagi pengelola, pemandu wisata dan pelaku usaha melalui pemanfaatan pemetaan potensi wisata halal yang dimiliki Stone Garden. Hal ini perlu dilakukan dikarenakan motivasi dan keterampilan komunikasi tidak dapat diperoleh dalam waktu yang singkat sehingga perlu pelatihan lanjutan. Untuk tindak lanjut pelaksanaan kegiatan pengabdian ini direncanakan akan dilakukan kerjasama dengan pihak Dinas Pariwisata Kabupaten Bandung Barat. Hal ini dilakukan karena permasalahan mengenai pengembangan potensi wisata halal di Kabupaten Bandung masih sangat minim. Diharapkan dengan pelatihan yang telah diberikan, para pengelola, pemandu wisata dan pelaku usaha di objek wisata Stone Garden dapat melakukan aktivitas Marketing Public Relations sebagai upaya perwujudan destinasi wisata halal di Kabupaten Bandung Barat.

\section{SIMPULAN}

Sesuai dengan hasil pembahasan menunjukkan bahwa pengetahuan mengenai pelaksanaan pengabdian kepada masyarakat yang yang terkait dengan teknik dasar marketing public relations yang disampaikan ke peserta sudah menunjukkan ada peningkatan. Hal ini dibuktikan dengan adanya beberapa pertanyaan seputar bagaimana beberapa pemandu memperlihatkan hasil aktivitas mereka dalam mempromosikan Stone Garden di media sosial para pengelola. Sedangkan untuk keterampilan peserta dalam memetakan masalah dan menemukan solusi untuk menjadikan Stone Garden sebagai objek wisata halal masih terbilang rendah. Tergolong rendah dibuktikan masih banyaknya para peserta yang tidak dapat mengemukakan ide mengenai konsep wisata halal saat proses simulasi berlangsung.

\section{UCAPAN TERIMA KASIH}

Ucapan terima kasih kami sampaikan kepada DRPMI Universitas Padjadjaran yang telah memfasilitasi pendanaan pelaksanaan PKM pada tahun 2018 ini.

\section{DAFTAR PUSTAKA}

[1]. Ade Ela Pratiwi. (2016). Analisis Pasar Wisata Syariah di Kota Yogyakarta. Media Wisata, 14, 345-364.

[2]. Adinugraha, H. H., Sartika, M., \& Kadarningsih, A. (2018). Desa wisata halal: konsep dan implementasinya di Indonesia. Human Falah, 5(1).

[3]. Anugrah, K., Mokodongan, A., \& Pulumodoyo, A. P. S. (2017). Potensi pengembangan wisata halal dalam perspektif dukungan ketersediaan restoran halal lokal (non waralaba) di kota gorontalo. Pesona, 2(02), 1-12.

[4]. Awalia, H. (2017). Komodifikasi Pariwisata Halal NTB dalam Promosi Destinasi Wisata Islami di Indonesia. Jurnal Studi Komunikasi, 1(1), 19-30.

[5]. Hardini, I., \& Puspitasari, D. (2012). Strategi pembelajaran terpadu: teori, konsep, dan implementasi. Yogyakarta: Familia.

[6]. Pratiwi, S. R., Dida, S., \& Sjafirah, N. A. (2018). Strategi komunikasi dalam membangun awareness wisata halal di kota Bandung. Jurnal Kajian Komunikasi, 6(1), 78-90.

[7]. Safira, A. M., Perbawasari, S., \& Sani, A. (2018). Proses Seleksi Lokasi Pada Program 
$\overline{I S S N}: 2550-0198$

Pemberdayaan Kelompok Sadar

Wisata di Kota Depok. Jurnal

Penelitian Komunikasi, 21(1), 87-

100.

https://doi.org/10.20422/jpk.v21i1.

204 